which not only universities, but also government and administrative bodies of the Russian Federation and public organizations should take part.

Keywords: academic mobility, national interests, information policy, foreign students, political socialization, political agenda

АРШИН Константин Валерьевич - ученый секретарь Федерального исследовательского центра картофеля им. А.Г. Лорха (140051, Россия, Московская обл., г. Любериы, пос. Красково, ул. Лорха, 23В; Kosta-10@yandex.ru)

\title{
ФАКТОР МИГРАЦИИ В РОСТЕ РЕЛИГИОЗНОЙ КОНФЛИКТОГЕННОСТИ (НА ПРИМЕРЕ ЕВРОПЫ): СОЦИАЛЬНО-ФИЛОСОФСКИЙ ПОДХОД
}

Аннотация. За последние годы в мире наблюдается не менее десятка конфликтов, которые либо ведутся представителями различных конфессий, либо осмысливаются как конфликты на религиозной почве. Это и гражданская война в Йемене, и конфликты в индийских штатах - Ассаме, Нагаленде и Манипуре, и конфликт в Мьянме между араканцами-буддистами и мусульманами-рохинджа. Часть этих конфликтов осмысливаются в качестве столкновения коренного населения и мигрантов. Однако и религиозный фактор играет в них значимую роль. В условиях нарастающей миграционной активности можно ожидать нарастания межрелигиозной конфликтности, в основе которой будет лежать миграционный фактор. Решение указанной проблемы видится в реализации проекта «конституционного патриотизма».

Ключевые слова: миграция, конфессия, конфликт, ислам, Европа, США, цивилизация, радикализм, идентичность

B 1996 г. американский политолог Самюэль Хантингтон в своей книге «Столкновение цивилизаций» выдвинул идею, согласно которой современный миропорядок поделен между 9 крупными наднациональными образованиями - цивилизациями [Хантингтон 2003]. В основе указанного разделения лежит господствующая в каждой из цивилизаций культурная доминанта, которая, в конечном счете, соотносится с той религией, которую исповедует большинство населения стран, объединенных Хантингтоном в цивилизацию. Так, в православную цивилизацию американский политолог включил непосредственно Российскую Федерацию, а также Беларусь и Украину; в исламскую цивилизацию - государства, население которых исповедует ислам (вне зависимости от того, какую ветвь); в конфуцианскую цивилизацию - Китай; в западную цивилизацию - государства Европы, а также страны переселенческого капитализма (США, Канада, Австралия, Новая Зеландия). Важнейшим в схеме Хантингтона был тезис о несовместимости цивилизаций, их принципиальной конфликтности, что означает принципиальную конфликтность культур, а значит и лежащих в основе культур религий.

Для современного мира, в котором миграция огромных масс людей стала насущной потребностью, а значит, взаимодействие представителей различных религиозных и этнических сообществ превратилось в повседневность, взрывоопасность позиции Хантингтона очевидна. Вместе с тем история последних 30 лет как будто бы подтверждает позицию американского политолога, несмотря на серьезную критику в его адрес [Russett, Oneal, Cox 2000; Sen 1999]. 
В 1990-х гг. на Балканском полуострове вспыхнула серия гражданских войн, в которые были вовлечены православные сербы, с одной стороны, хорватыкатолики - с другой, мусульмане-босняки - с третьей. В Ирландии не утихал конфликт между представителями католического большинства и протестантского меньшинства.

В начале нулевых годов конфликт между США и рядом ближневосточных государств (Афганистан, Ирак) осмысливался в публичном пространстве в т.ч. как религиозный конфликт, в результате чего нападению подвергались исповедующие ислам американцы, а также мусульманские культовые сооружения. В это же время в Европе началась активная фаза выступлений мусульманской молодежи второго и третьего поколения мигрантов, вылившаяся в серию беспорядков, подавить которые стоило огромного труда. Осознание проблемы, с которой столкнулась Европа, выкристаллизовалось в уничижительном термине «Еврабия», которым обозначалась зависимость Европы от арабо-мусульманского влияния [Эш 2007].

Начало 2010-х гг. было ознаменовано еще большей религиозной конфликтностью. Арабская весна и последовавшие за ней потоки беженцев-мусульман в Европу привели к росту популярности антииммигрантских популистских партий, полагающих себя бастионом борьбы против исламизации европейских государств. Упомянем также резню араканцами-буддистами мусульманрохинджа в Мьянме. Балансируют на грани войны отношения между индуистской и мусульманской общинами в Индии. Впрочем, и внутри самих религиозных конфессий было не все спокойно. В Йемене началась гражданская война между суннитским правительством и хуситами, в Сирии не прекращаются боевые столкновения между суннитами, шиитами и алавитами.

Общим для большинства подобных конфликтов выступают следующие позиции:

- со стороны коренного населения: пришельцы (мигранты) своими действиями наносят вред полноценному развитию коренного населения;

- со стороны мигрантов: коренное население создает препятствия для полноценной интеграции мигрантов в новый социум.

Наиболее ярко проявление указанных позиций можно наблюдать при взаимодействии мигрантов-мусульман и коренного населения европейских государств. Указанное взаимодействие особенно остро ставит вопрос об идентичности мигрантов-мусульман второго поколения. Вот как его характеризует американский политолог Френсис Фукуяма в своей новой книге «Идентичность: стремление к признанию и политика неприятия»: «Они [мигранты второго поколения] живут преимущественно в светских обществах с христианскими корнями, публично не принимающих исламские религиозные ценности и обычаи. <...> Как и многие дети иммигрантов, они стремятся дистанцироваться от старомодного образа жизни своих семей. Однако им нелегко интегрироваться в новую европейскую среду: уровень безработицы среди молодежи, особенно среди мусульман, превышает $30 \%$, да и зависимость от этнической принадлежности и принадлежности к доминирующему культурному сообществу во многих европейских странах по-прежнему остается сильной» [Фукуяма 2019: 97]. Результатом становится «межеумочная жизнь» (термин, которым британский интеллектуал Тимоти Гартон Эш обозначил состояние, при котором мигрант не чувствует себя дома ни в стране происхождения, ни в стране проживания). «Межеумочная жизнь» не только способствует формированию культурного раздвоения личности, но и приводит к реальным психологическим проблемам. Так, голландский историк Йен Бурума приводит слова одного психиатра, исследования которого показали, что «у марокканского 
мужчины из второго поколения [мигрантов] вероятность стать шизофреником в десять раз выше, чем у коренного голландца, занимающего такое же социальное положение» [Эш 2007: 192]. Похожие идеи высказывает и Ф. Фукуяма, заявляющий, что «европейские мусульмане, в частности, второго поколения, обнаружили себя между двумя культурами - культурой родителей, которую они отвергают, и культурой новой родины, которая не принимает их в полной мере» [Фукуяма 2019: 100]. Результатом этого становится обращение к умме, предлагающей идентичность и гордость за то, кем они являются - не париями, которые прозябают на периферии гетто, созданного европейским обществом, а членами «гордой и древней общины» верующих, раскинувшейся по всему миру [Фукуяма 2019: 98]. Будучи неофитами, они крайне остро воспринимают нападки на вновь обретенную веру и легко подпадают под влияние воинственных проповедников, которые утверждают в них враждебность к миру и пестуют их радикализм. Это приводит к крайне радикальным, заслуживающим исключительно осуждения эксцессам (например, убийство голландского режиссера Тео ван Гога в 2004 г., расстрел редакции журнала «Charlie Hebdo» в 2015 г., увеличивающееся число террористических актов). Пролонгированное последствие подобных действий - рост отчуждения между мигрантами и принимающим обществом. История мусульманки Норы, признавшейся Тео ван Гогу, что перед нападениями на Нью-Йорк 11 сентября она «была просто Норой. Потом внезапно я стала мусульманкой» [Хантингтон 2003: 197], становится все более распространенной.

В итоге наблюдается замкнутый порочный круг. Но из него есть выход. Прежде всего, следует признать необходимость проведения последовательной политики интеграции и ассимиляции. Указанная политика должна строиться на включении иммигрантов в публичную политическую культуру принимающего сообщества. Причем это включение должно осуществляться на принципах справедливости, что, с одной стороны, требует равного и беспристрастного применения как к мигрантам, так и к коренным гражданам законов государства, а с другой - возможности применения к мигрантам правового компромисса в той мере, в какой он применяется к коренным гражданам [Шеффлер 2007].

Впрочем, действия государства - это лишь вершина айсберга. Многое зависит от самого принимающего общества, его готовности идти на компромиссы, его терпимости по отношению к законопослушным мигрантам, понимания им той пользы, которую несет миграция.

В 2018 г. специалисты Института этнологии и антропологии РАН провели опрос экспертов по миграционной проблематике о влиянии миграции на социально-экономическую ситуацию в г. Москве. Результаты опроса показали, что $60 \%$ респондентов полагают, что мигранты оказывают положительное влияние на демографическое развитие российской столицы. Для $40 \%$ опрошенных такое влияние было скорее отрицательным. По показателю оценки влияния миграции на развитие экономики региона голоса экспертов разделились следующим образом: 77\% респондентов оценили такое влияние положительно, а $22 \%$ респондентов - отрицательно. При этом значительная часть экспертов отрицательно оценили влияние миграции на социальную обстановку в столичном мегаполисе. В качестве наиболее страдающих отраслей городского хозяйства в порядке убывания были названы: социальная и транспортная инфраструктура, криминогенная ситуация, занятость и безработица, уровень заработных плат и доходов населения. На вопрос: «Что важнее для развития Вашего региона на ближайшие годы - сократить численность иностранной рабочей силы, или увеличить, или оставить без изменения?» - большинство 
опрашиваемых ответили - «оставить без изменения, как есть в настоящее время» [Зорин 2019].

Как было отмечено выше, опрос Института этнологии и антропологии РАН носил экспертный характер. Однако его выводы коррелируют с результатами всероссийского опроса об отношении россиян к миграционной политике страны и мигрантам из стран СНГ, проведенного ВЦИОМом в 2016 г. Так, по данным ВЦИОМа, 71\% россиян отрицательно относятся к идее упрощения процедуры получения мигрантами российского гражданства. Более того, $36 \%$ опрошенных отстаивают идею ее ужесточения. Так же критично россияне относились к вопросу проведения миграционной амнистии. За ее проведение высказалось только 36\%, 59\% отнеслись к ней отрицательно. Комментируя результаты опроса, директор специальных программ ВЦИОМа Елена Михайлова отметила, что подобное отношение россиян к проводимой в стране миграционной политике определяется как внутриполитическими, так и внешнеполитическими факторами. К внутриполитическим факторам она отнесла нестабильную экономическую ситуацию и непрогнозируемость ситуации на рынке труда, к внешнеполитическим - активно освещающиеся в российских средствах массовой информации проблемы, «с которыми столкнулись европейские страны в результате неконтролируемого притока мигрантов» ${ }^{1}$. Вместе с тем уровень ксенофобии в российском обществе стабильно снижается. На встрече с президентом РФ В.В. Путиным глава Федерального агентства по делам национальностей И.В. Баринов сообщил следующее: «Согласно нашему [ФАДН] показателю 96 процентов населения нашей страны за прошедший год не имели проблем в связи со своей национальностью в быту, на работе, в транспорте, на улице. 87 процентов не испытывают раздражения или вражды к представителям других национальностей» ${ }^{2}$. Слова руководителя ФАДН России подтверждаются статистикой числа проявлений актов ксенофобии. Как указывается в докладе Московского бюро по правам человека за 2019 г., по сравнению с предшествующим (2018) годом фиксируется снижение как общего числа нападений на почве ксенофобии (с 24 случаев до 12), так и фактов вызванного ксенофобией вандализма (с 26 случаев до 24) ${ }^{3}$.

Однако ксенофобия, будучи психологическим феноменом, достаточно легко может вернуться под влиянием изменения социальных условий. Также под влиянием ухудшения социальных условий возможны как рост антииммигрантских настроений среди коренного населения, так и рост экстремизма среди мигрантов (причем не только первого, но и второго-третьего поколений). Снижение влияния социальных факторов на экстремизацию общественного сознания видится в необходимости реализации социального проекта по включению мигрантов в общество страны-реципиента. В настоящее время существует ряд проектов того, как это можно сделать. Наиболее рациональным и осуществимым среди них выглядит проект «конституционного патриотизма» Ю. Хабермаса. Суть его заключается в необходимости формирования политической культуры, отделенной от субкультур, сосуществующих в обществе отдельных сообществ. В основе этой политической культуры должны лежать: 1) соответствие ценностей субкультур значимым принципам государственного

\footnotetext{
1 Иммигранты из стран СНГ в Россию: любим, но... Не ждем! Доступ: https://wciom.ru/ index.php?id=236\&uid=116061 (проверено 27.10.2020).

2 Встреча с руководителем Федерального агентства по делам национальностей Игорем Бариновым. Доступ: http://www.kremlin.ru/events/president/news/64196 (проверено 27.10.2020).

3 Правозащитники отметили спад числа проявлений ксенофобии в России. - РИА Новости. 01.04.2020 Доступ: https://ria.ru/20200401/1569423668.html (проверено 27.10.2020).
} 
устройства; 2) единая интерпретация провозглашенных конституцией страны принципов.

Последнее достигается путем внутригосударственной дискурсивной практики, которую ведут представители всех присутствующих в обществе субкультур. Причем эта практика становится возможной именно благодаря существованию субкультур. Это оборачивается возможностью сохранения множественной идентичности, позволяющей «быть в собственной стране и ее жителем, и чужаком» [Хабермас 2001]. В рамках миграционной проблемы это означает, что, вступая в дискурсивную практику, которая делает возможным существование «конституционного патриотизма», мигрант не должен отказываться от своей идентичности, что, как было показано выше, и служит одной из причин экстремизма. Наоборот, само сохранение этой идентичности обеспечивает возможность реализации той формы социального взаимодействия в условиях поддержания социальной безопасности, которую мигрант рассматривает как желательную, или, говоря словами Ю. Хабермаса, обеспечивает мигранту возможность приобретать «свою долю в социальной и культурной жизни» [Хабермас 2001]. В свою очередь, коренному населению подобная двойная идентичность обеспечивает психологический комфорт, необходимый для поддержания стабильных межнациональных отношений и снижения уровня ксенофобии, поскольку демонстрирует отсутствие посягательств со стороны мигрантов на принятые в социуме-реципиенте нормы и принципы социальной жизни.

\section{Список литературы}

Зорин В.Ю. 2019. Миграционная политика между правами человека и безопасностью. - Наука. Общество. Оборона. Доступ: https://www.noo-journal.ru/ migratsiya-demografiya/zorin-v-migratsiya/ (проверено 27.10.2020).

Шеффлер С. 2007. Иммиграция и значение культуры. - Прогнозис. № 1(9). C. 77-102.

Хабермас Ю. 2001. Вовлечение другого. Очерки политической теории. СПб: Наука. 417 с.

Хантингтон С. 2003. Столкновение цивилизаций. М.: АСТ. 603 с.

Фукуяма Ф. 2019. Идентичность: стремление к признанию и политика неприятия. М.: Альпина-Паблишер. 256 с.

Эш Т.Г. 2007. Ислам в Европе. - Прогнозис. № 1(9). С. 186-199.

Russett B.M., Oneal J.R., Cox M. 2000. Clash of Civilizations, or Realism and Liberalism Déjà Vu? Some Evidence. - Journal of Peace Research. Vol. 37. Is. 5. P. 583-608.

Sen A. 1999. Democracy as a Universal Value. - Journal of Democracy. Vol. 10. Is. 3. P. 3-17. 
ARSHIN Konstantin Valerievich, Scientific Secretary of the Russian Potato Research Center (23B Lorcha St, Kraskovo, Lubertsy, Moscow Region, Russia, 140051; Kosta-10@yandex.ru)

\title{
MIGRATION AS A FACTOR OF THE GROWTH OF RELIGIOUS CONFLICT POTENTIAL (ON THE EXAMPLE OF EUROPE): THE SOCIO-PHILOSOPHICAL APPROACH
}

\begin{abstract}
In recent years, one can observe at least a dozen conflicts in the world, which either are waged by representatives of various faiths, or are interpreted as conflicts on religious grounds. These are the civil war in Yemen, the conflicts in the Indian states of Assam, Nagaland and Manipur, and the conflict in Myanmar between Arakanese Buddhists and Rohingya Muslims. Some of these conflicts are interpreted as a clash between the indigenous people and migrants. However, the religious factor also plays a significant role. In the context of increasing migration activity, it is possible to expect an increase in inter-religious conflict, based on the migration factor. The solution to this problem is seen in the implementation of the project of constitutional patriotism.
\end{abstract}

Keywords: migration, confession, conflict, Islam, Europe, USA, civilization, radicalism, identity

ВИНОГРАДОВА Надежда Сергеевна - кандидат политических наук, доцент кафедры общественных процессов, средств массовой информации и рекламных технологий Московского государственного университета технологий и управления им. К.Г. Разумовского (ПКУ) (109004, Россия, 2. Москва, ул. Земляной Вал, 73; nadivinogradova@gmail.com)

\section{РОЛЬ ОФИЦИАЛЬНОЙ РИТОРИКИ МЕЖДУ РФ И США В ПРОЦЕССЕ ФОРМИРОВАНИЯ ОБРАЗА РОССИИ (2009-2019 гг.)}

\begin{abstract}
Аннотация. Образ России, как и образ любой страны, претерпевает постоянные изменения. В начале 1990-х Россия ориентирована на демократический мир. Образ претерпевает серьезные изменения в нулевых, после выступления президента РФ В.В. Путина на Мюнхенской конференции по вопросам безопасности, в котором президент РФ обозначил национальные интересы России. В 2010-х ситуация кардинально меняется, т.к. Россия поддержала объединение России и Крыма по итогам референдума, таким образом защищая не только национальные интересы, но и интересы русскоговорящего мира. В рамках исследования использовался контент-анализ официальных публикаций. Объектом анализа стали 4828 официальных публикаций.
\end{abstract}

Ключевые слова: образ России, международная дипломатическая риторика, сайт Администрации Президента РФ, сайт Администрации Президента США, сайт Министерства иностранных дел России, сайт Госдепартамента США

\section{Введение}

Исторически дипломатические отношения между Россией и США развивались волнообразно: в период Советского Союза до начала Второй мировой войны отношения были прохладными, однако в период президентства Ф. Рузвельта характеризовались полным взаимопониманием. Ярким примером этого являются ряд встреч первых лиц, например Ялтинская-Тегеранская 